МОВНИЙ БАР'ЄР ЯК КЛЮЧОВА ПЕРЕПОНА АДЕКВАТНОЇ АДАПТАЦІї ТА СОЦІАЛІЗАЦІЇ ІНОЗЕМНИХ СТУДЕНТІВ У МЕДИЧНОМУ ОСВІТНЬОМУ ПРОСТОРІ УКРАЇНСЬКОГО СУСПІЛЬСТВА

\author{
LANGUAGE BARRIER AS A KEY BARRIER TO ADEQUATE ADAPTATION \\ AND SOCIALIZATION OF FOREIGN STUDENTS IN MEDICAL EDUCATIONAL \\ SPACE OF UKRAINIAN SOCIETY
}

УДК 376.68:378.14;159.953.5

DOI https://doi.org/10.32843/2663-

5208.2020 .15 .41

\section{Катрушова л.о.}

аспірант каседри загальної, вікової

та практичної психології

Полтавський національний педагогічний університет імені В.Г. Короленка у статті розглядається роль мовного бар'єру як ключової перепони адекватної адаптації та соціалізації іноземних студентів у медичному освітньому просторі українського суспільства. Протягом останніх років в Украйну прибувають для отримання вищої медичної освіти іноземні студенти більше ніж із 130 країн. Адаптація студентів до навчання в навчальному закладі вищої освіти є складним і багатогранним процесом, а його успішність залежить від низки зовнішніх і внутрішніх чинників. Адаптація до нових умов на побутовому рівні відбувається відносно швидко, а от усе, що стосується засвоєння професійних знань у межах освітянського простору, може займати досить тривалий період часу. Метою роботи $\epsilon$ дослідження значимості мовного бар'єру як вірогідної ключової перепони успішності навчання та адекватної адаптації й соціалізації іноземних студентів у медичному освітньому просторі Українського суспільства. Дослідження проведені на базі фракультету підготовки іноземних студентів Українсько медичної стоматологічної академії шляхом анкетування студентів російськомовного та англомовного навчання першого, третього й шостого курсів. Усього в дослідженні взяли участь 213 студентів у період 2017-2018 навчального року. Для визначення рівня соціальної адаптації проводилося анкетування за адаптованим тестом Л.В. Янковського російською та англійською мовами. У роботі використані статистичні дані показників успішності студентів залежно від мови викладання. Аналіз динаміки соціальної адаптації студентів-іноземців в освітянському та соціальному просторі Українського суспільства показав, що група студентів російськомовного навчання демонструє кращі значення рівня соціальної адаптації порівняно зі студентами англомовного навчання, що можна пояснити більш успішним подоланням мовного бар'єру передусім в умовах побуту й культурного середовища, що також позитивно відображається на успішності навчання.
Ключові слова: студенти-мігранти, мовний бар'єр, соціальна адаптація.

The article considers the role of the language barrier as a key obstacle to adequate adaptation and socialization of foreign students in the medical educational space of Ukrainian society. In recent years, foreign students from more than 130 countries have been coming to Ukraine to receive higher medical education. Adaptation of students to study in higher education is a complex and multifaceted process, and its success depends on a number of external and internal factors. Adaptation to new conditions at the household level is relatively fast, but everything related to the acquisition of professional knowledge within the educational space can take quite a long period of time. The aim of the work was to study the significance of the language barrier as a probable key obstacle to academic success and adequate adaptation and socialization of foreign students in the medical educational space of Ukrainian society. The research was conducted on the basis of the faculty of training foreign students of the Ukrainian Medical Dental Academy by questioning students of Russian and English first, third and sixth year students. A total of 213 students took part in the study in the 2017-2018 academic year. To determine the level of social adaptation, a survey was conducted according to the adapted test of Yankovsky LV in Russian and English. The statistical data of student performance indicators depending on the language of instruction were used in the work. Analysis of the dynamics of social adaptation of foreign students in the educational and social space of Ukrainian society showed that a group of Russian-speaking students shows better values of the level of social adaptation compared to English-speaking students, which can be explained by more successful overcoming of the language barrier. and cultural environment, which also has a positive effect on learning success.

Key words: migrant students, language barrier, social adaptation.
Постановка проблеми. Наукова проблема полягає в тому, що на цьому етапі існування Українського суспільства, коли освітянський простір прогресивно поповнюється студентами-мігрантами, виникла необхідність більш поглибленого дослідження причин соціальної дисадаптації студентів-іноземців в умовах Українського освітнього простору. Протягом останніх років в Україну прибувають для отримання вищої медичної освіти іноземні студенти більш ніж із 130 країн. Переважно це студенти з країн Арабського сходу, Індії, Ірану, Китаю, Малайзії, Молдови, Туреччини й Узбекистану. Особливості морально етичних норм етнічних груп, культурних цінностей, традицій і звичаїв, систем віросповідання - усе це накладає свій відбиток на психологічний стан студента, який опинився в новому для нього мовному, соціальному, політичному та економічному середовищі. Адаптація до нових умов на побутовому рівні відбувається відносно швидко, а от усе, що стосується засвоєння 
професійних знань у межах освітянського простору, може займати досить тривалий період часу [3, с. 35; 10, с. 47]. Роль мовного бар'єру в цьому процесі недостатньо досліджена, мало висвітлена в літературі та потребує більш детального вивчення.

Аналіз останніх досліджень і публікацій. Адаптація студентів до навчання в навчальному закладі вищої освіти $є$ складним і багатогранним процесом, а його успішність залежить від низки зовнішніх і внутрішніх чинників [1, с. 42; 4, с. $7 ; 7$, с. $31 ; 8$, с. 147]. Одним із провідних чинників адекватної адаптації та соціалізації іноземних студентів є висока функціональна спроможність другої сигнальної системи, що нівелює мовний бар'єр і сприяє успішності навчання, адаптації та соціалізації $[1$, с. 74 ; 5, с. 69]. Це зумовлює необхідність поглибленого дослідження проблем дисадаптації, так як ефективна професійна підготовка майбутнього лікаря не може здійснюватися без високого ступеня асиміляції студента в навчальний процес [2, с. 175; 4, с. 8].

Згідно з І.П. Павловом, у людей існує дві сигнальні системи подразників: перша - це безпосередній вплив внутрішнього та зовнішнього середовища на різні рецептори (ця система присутня також в інших істот), друга сигнальна система - система мовних знаків, символів (письмових чи усних), які викликають у людини такі самі реакції, як і реальні об'єкти, що цими символами позначені. Причому лише незначна частина цих слів маніфестує сенсорні впливи на людину. Робота другої сигнальної системи полягає насамперед в аналізі й синтезі узагальнених мовних сигналів [9, с. 73]. Єдина сигнальна система у тварин і перша в людини забезпечують відображення дійсності у вигляді безпосередніх чуттєвих образів. Це «то, что мы имеем в себе впечатление, ощущение и представление от окружающей внешней среды, как общеприродной, так и нашей социальной, исключая слово, слышимое и видимое» [9, с. 146].

Найбільш яскравим прикладом значимості другої сигнальної системи для соціалізації особи в суспільстві, плідної співпраці, навчання тощо є біблійний переказ міфу про Вавилонську башту, який викладений в 11 розділі книги Буття (Бут. 11:1-9). Цей приклад загальновідомий і не потребує детального опису.

Постановка завдання. Мета статті дослідити значимість мовного бар'єру як вірогідної ключової перепони успішності навчання та адекватної адаптації й соціалізації іноземних студентів у медичному освітньому просторі Українського суспільства.

Матеріал і методи. Для досягнення поставленої мети проведені дослідження на базі факультету підготовки іноземних студентів Української медичної стоматологіч- ної академії шляхом анкетування студентів російськомовного й англомовного навчання першого, третього та шостого курсів. Усього в дослідженні взяли участь 213 студентів у період 2017-2018 навчального року. Анкетування проводилося за адаптованим тестом Л.В. Янковського $[6$, с. $31 ; 12$, с. 206] російською та англійською мовами. Для тестування першокурсників російськомовного навчання використані тести, перекладені рідною мовою студента. Так як психологічні тести потребують глибокого знання мови для правильного розуміння нюансів поставлених тестових запитань, то розраховувати на достовірні відповіді під час тестування студентів-іноземців першого курсу навчання за допомогою російськомовних тестів не доводиться. Це продемонстрували наші попередні дослідження, коли ідентичні тести російською мовою та рідною мовою студента-першокурсника дали незіставні результати. Ми виражаємо подяку клінічним ординаторам-іноземцям УМСА як носіям мови за допомогу в перекладі задіяних у дослідженнях психологічних тестів мовами основних етнічних груп студентів, що навчаються в Академії. Аналіз успішності навчання студентів проводили за контрольним іспитом «КРОК 1 » «КРОК 2».

Виклад основного матеріалу дослідження. Останніми роками у зв'язку з глобальними соціально-економічними системними змінами у світі та зростаючими темпами міждержавної освітянської міграції молоді інтерес до проблем соціальної адаптації широких контингентів студентської молоді в нових умовах «чужого» суспільства не тільки не втрачає своєї актуальності, а й постійно зростає. Освітньою міграцією називають переважно тимчасове переселення, що триває від кількох місяців до кількох років й має на меті навчання за межами адміністративно-територіальної одиниці постійного проживання [11, с. 131].

Дослідження прогнозованих вірогіднісних проблем, пов'язаних із дезадаптацією студентів-іноземців у медичному освітньому середовищі України, важливо розпочинати з аналізу механізмів виникнення проблемних ситуацій адаптації, що можуть призводити до девіантності поведінкових реакцій особи.

Адаптація людини в широкому розумінні цього терміна $€$ дуже важливе поняття в різних наукових підходах, так як здатність пристосуватися до навколишнього середовища (біологічного, соціального, етнічного) необхідна в усіх сферах життя. Адаптація особи в будьякому середовищі - це складний багатоплановий процес, що може вносити зміни в різні системи організму людини й залежить від рівня впливу чинника та терміну його дії. А так як освітянська міграція - процес довготривалий, який розтягується на роки (для студен- 
тів-медиків це 6-8 років), то процеси адаптації торкаються глибоких механізмів регуляторних процесів з перебудови динамічного стереотипу реагування на різноманітні чинники середовища перебування особи [4, с. 3].

Згідно з класифікацією, адаптація підрозділяється на біологічну, соціальну, етнічнутапсихологічну. Соціально-психологічна адаптація передбачає пристосування однієї чи декількох осіб до соціального середовища, яке пред'являє вимоги і ставить умови співіснування за визначеними критеріями, що дає особі змогу досягти мети без порушення морально-етичних принципів існування суспільства. Це особливо значимо в умовах освітянської міграції, так як включає пристосування до навчання, до стосунків з іншими людьми, до нового культурного та релігійного оточення.

Під час освітянської міграції важливим видом адаптації $є$ етнічна, яка розглядається як підвид соціальної адаптації, що включає пристосування окремих етнічних груп до середовища регіонів їх розселення в нових умовах, причому мова йде як про соціальні, так і про погодно-кліматичні умови. Це найбільш своєрідний вид адаптації, який спричиняють відмінності в мовно-культурній, політичній, економічній та інших сферах.

Окремо варто відмітити психологічну адаптацію, яка зараз $є$ найважливішим соціальним критерієм, що дає змогу оцінювати особу як у сфері взаємовідношень, так і у сфері професійної стабільності. Залежить психологічна адаптація від багатьох мінливих чинників, до яких належать мотивація, мовний бар'єр, особливості характеру, соціальне оточення, віросповідання тощо.

Виходячи 3 вищевикладеного, можна окреслити провідні вектори, що сприяють адекватній адаптації та соціалізації студентів-іноземців в умовах українського суспільства під час освітянської міграції.

Особистісно-мотиваційне ставлення до ЗВО та навчання: бажання (чи небажання) приймати навчальні завдання, виконувати завдання педагога, іншими словами, навчатися. Прийняття навчального завдання: розуміння завдань, поставлених педагогом; бажання їх виконувати; прагнення до успіху чи бажання уникнути невдачі. У цьому ракурсі надзвичайно важливим є подолання мовного бар'єру, так як навчання неможливе без глибокого розуміння інформації, що надається як усно, так і в друкованому вигляді. Для студента-медика це особливо важливо, так як, окрім засвоєння матеріалу, що викладається українською, російською чи англійською мовами (залежно від профілю підготовчого відділення), обов'язковим $€$ вивчення латинської мови й термінології. А цю ситуацію можна розглядати як подвійне навантаження на спроможність подолання мовного бар'єру. Також важливим $є$ те, що за процесом засвоєння інформації іде її осмислення, асоціативний аналіз і синтез відповіді на поставлене завдання (проведення диференціального діагнозу, складання плану лікування, медичне прогнозування наслідків розвитку хвороби, вірогідність ускладнень тощо).

Таблиця 1

Порівняльна характеристика показників успішності студентів Української медичної стоматологічної академії залежно від мови викладання

\begin{tabular}{|c|c|c|c|}
\hline \multicolumn{2}{|c|}{ Екзамен } & К-сть студентів & Середній показник успішності за тестами \\
\hline \multirow{2}{*}{$\begin{array}{c}\text { Крок 1 } \\
\text { (3 курс) }\end{array}$} & рос. мова & 36 & $50,8 \%$ \\
\cline { 2 - 4 } & англ. мова & 33 & $59,8 \%$ \\
\hline \multirow{2}{*}{$\begin{array}{c}\text { Крок 2 } \\
\text { (6 курс) }\end{array}$} & рос. мова & 34 & $76,2 \%$ \\
\cline { 2 - 4 } & англ. мова & 31 & $72,6 \%$ \\
\hline
\end{tabular}

Порівняльна оцінка показників соціальної адаптації студентів-мігрантів УМСА залежно від мови викладання та часу перебування в новому соціокультурному середовищі (тест Л.В. Янковського) [12, с. 206]

\begin{tabular}{|l|c|c|c|c|c|c|}
\hline \multicolumn{1}{|c|}{ Курс навчання } & \multicolumn{2}{|c|}{$\mathbf{\text { курс }}$} & \multicolumn{2}{c|}{ 3 курс } & \multicolumn{2}{c|}{$\mathbf{6}$ курс } \\
\hline $\begin{array}{c}\text { Мова навчання/ } \\
\text { к-сть респондентів }\end{array}$ & $\begin{array}{c}\text { рос. мова } \\
\text { (42) }\end{array}$ & $\begin{array}{c}\text { англ. мова } \\
\text { (37) }\end{array}$ & $\begin{array}{c}\text { рос. мова } \\
\text { (36) }\end{array}$ & $\begin{array}{c}\text { англ. мова } \\
\text { (33) }\end{array}$ & $\begin{array}{c}\text { рос. мова } \\
\text { (34) }\end{array}$ & $\begin{array}{c}\text { англ. мова } \\
\text { (31) }\end{array}$ \\
\hline Шкала адаптивності & $4,3 \pm 0,3$ & $2,6 \pm 0,2$ & $7,3 \pm 1,8$ & $5,4 \pm 0,6$ & $12,6 \pm 1,3$ & $9,2 \pm 0,8$ \\
\hline Шкала конформності & $5,6 \pm 0,5$ & $4,3 \pm 0,6$ & $8,6 \pm 0,7$ & $6,1 \pm 0,5$ & $11,3 \pm 1,7$ & $8,4 \pm 0,9$ \\
\hline Шкала інтерактивності & $5,9 \pm 0,8$ & $4,7 \pm 0,5$ & $8,3 \pm 1,2$ & $6,4 \pm 0,7$ & $12,7 \pm 1,4$ & $9,7 \pm 1,1$ \\
\hline Шкала депресивності & $12,3 \pm 2,1$ & $13,3 \pm 1,9$ & $10,6 \pm 1,4$ & $12,2 \pm 1,2$ & $7,4 \pm 0,9$ & $10,5 \pm 0,9$ \\
\hline Шкала ностальгії & $13,4 \pm 2,4$ & $15,3 \pm 2,3$ & $12,2 \pm 0,9$ & $13,5 \pm 1,2$ & $6,6 \pm 0,9$ & $8,7 \pm 0,7$ \\
\hline Шкала відчуженості & $13,3 \pm 2,1$ & $14,6 \pm 2,8$ & $10,4 \pm 1,1$ & $12,3 \pm 1,6$ & $7,3 \pm 0,8$ & $10,3 \pm 1,0$ \\
\hline
\end{tabular}

Примітка: високий рівень - якщо показник суми балів перевищує 12; середній рівень - від 6 до 12; низький рівень - менше ніж 6 балів. 
Одним із провідних критеріїв адекватної адаптації студентів в освітньому просторі $€$ показники успішності навчання - поточна успішність, результати підсумкових модульних контролів, результати екзаменів. Але для медичних ЗВО України найбільш об'єктивними критеріями вважаються контрольні іспити «КРОК 1» і «КРОК 2», які проводяться центром тестування при МОЗ України.

Представлені в таблиці 1 дані демонструють значні відмінності показників успішності за результатами 3 і 6 років навчання студентів залежно від мови викладання. Суттєво більш низький (на 9\% після 3-х років навчання) якісний показник успішності в групі студентів із російськомовним викладанням можна пояснити недостатнім подоланням мовного бар'єра студентами-іноземцями. Однак після 6 років навчання показники успішності студентів значно покращуються, причому в групах російськомовного викладання вони на 3,6\% виші, ніж у групах англомовного викладання.

Шкали адаптивності, конформності й інтерактивності містять інформаційний складник позитивного розвитку соціальної адаптації, так як свідчать про особисту задоволеність, позитивне ставлення до оточення, відчуття соціальної та фізичної захищеності; прагнення за будьяких умов підтримувати взаємини з людьми; орієнтацію на соціальне схвалення; демонструють активне входження в нове соціальне середовище; настроєність на розширення соціальних зв'язків; спрямованість на співробітництво; контроль над власною поведінкою з урахуванням соціальних норм. Як випливає з даних таблиці 2, спостерігається стійка односпрямована тенденція підвищення показників за вказаними шкалами в обох групах спостереження з плином часу. Після трьох років навчання ці показники піднімаються з рівня «низький» до рівня «середній», а після шести років - до рівня «високий» статистично вірогідно в групі російськомовного навчання за шкалами адаптивності й інтерактивності $(P<0,01)$. Однак залишаються в межах рівня «середній» у групі спостереження англомовного навчання. Таке відставання процесу соціалізації англомовних студентів в умовах українського суспільства можна пояснити наявністю мовного бар'єру поза межами освітянського простору (в побуті, культурному середовищі тощо).

Високі показники за шкалами репресивності, ностальгії та відчуженості характеризують негативний вектор соціалізації, а саме говорять про дисгармонію особистості, утрату зв'язку 3 культурним середовищем рідного суспільства, відчуття, що людина «не на своєму місці», характерні меланхолія, спустошеність. відчуття безпритульності, неприйняття нового соціуму; низька самооцінка; невідповідність домагань і реальних можливо- стей; незадоволення своїм статусом, неспроможність задовольнити свої потреби, паніка, безпомічність, відчуття покинутості. Згідно з даними таблиці 2, на початковому етапі входження студентів-іноземців в освітній простір українського суспільства показники за вищевказаними шкалами демонструють високі значення рівня дисадаптації (сума балів перевищує значення 12). Проте в процесі навчання відбувається прогрес соціальної адаптації, про що свідчить зниження показників до рівня «середній». Однак навіть після шести років навчання показники за шкалами депресивності, ностальгії та відчуженості не виходять за рамки середнього рівня в обох групах спостереження. Можна відмітити, що група студентів російськомовного навчання демонструє дещо кращі значення рівня соціальної адаптації порівняно зі студентами англомовного навчання, що можна пояснити більш успішним подоланням мовного бар'єру передусім в умовах побуту та культурного середовища.

Висновки з проведеного дослідження. Аналіз динаміки соціальної адаптації студентів-іноземців в освітянському й соціальному просторі Українського суспільства показав, що група студентів російськомовного навчання демонструє кращі значення рівня соціальної адаптації порівняно зі студентами англомовного навчання, що можна пояснити більш успішним подоланням мовного бар'єру передусім в умовах побуту та культурного середовища, що також позитивно відображається на успішності навчання.

\section{ЛITEРАТУРА:}

1. Агличева И.В. Комплексное исследование особенностей личностной адаптации студентов ВУЗа : дисс. ... канд. психол. наук : 19.00.01. Ставрополь, 2006. 233 c.

2. Албитова К.П. Социальная адаптация студентов ВУЗа на основе педагогической поддержки : дис. ... канд. пед. наук : 13.00.01. Улан-Удэ, 2015. 258 с.

3. Белов В.В., Корзунин В.А. Психологическое сопровождение личностного развития студентов в ВУЗе. Вестник ЛгУ им. А.С. Пушкина. 2015. Т. 5. № 4. С. 33-45.

4. Гречкина Л.Ю. Изучение процессов адаптации студентов вуза. Вестник БГУ. 2017. Вып. 1. С. 3-9.

5. Грушевський В.О. Особливості соціально-психологічної адаптації студентів-першокурсників до навчання у ВН3. Науковий вісник Миколаївського національного університету імені В.О. СухомлинСького. 2014. № 2.12. С. 67-72.

6. Дубовицкая Т.Д., Крылова А.Я. Методика исследования адаптированности студентов в вузе. Психологическая наука и образование. 2010. № 2. С. 27-46.

7. Маклаков А.Г., Головешкин И.Д. Особенности адаптации студентов первого курса к образовательной среде ВУЗа. Вестник ЛгУ им. А.С. Пушкина. 2011. № 3. C. 29-37. 


\section{ГАБІТУC}

8. Москаленко В.В. Соціалізація особистості : монографія. Київ : : Фенікс, 2013. 540 с.

9. Павлов И.П. Полн. собр. соч. Москва, 1951. Т. 3. Кн. 2. С. 345.

10. Раднаева М.В., Шибанова Ю.В. К вопросу адаптации студентов на начальном этапе обучения в ВУЗе. Вестник БГУ. 2016. Вып. 1. С. 44-49.
11. Ровенчак О. Визначення та класифрікації міграцій: наближення до операційних понять. Політичний менеджмент. 2006. № 2 (17). С. 127-139.

12. Сонин В.А. Психодиагностическое познание профеессиональной деятельности. Санкт-Петербург, 2004. C. 206-211. 